\title{
The Urgency of Virtual Tour for Sumatran Butterfly Conservation
}

\author{
Meizano Ardhi Muhammad ${ }^{1 *}$, Gita Paramita Djausal ${ }^{2,}$ Martinus $^{3,}$ Sony Ferbangkara ${ }^{4}$,
}

\author{
Alia Larasati ${ }^{5}$ \\ ${ }^{1}$ Informatics Engineering Department, Faculty of Engineering, Universitas Lampung \\ ${ }^{2}$ Business Administration Department, Faculty of Social and Political Sciences, Universitas Lampung \\ ${ }^{3}$ Mechanical Engineering Department, Faculty of Engineering, Universitas Lampung \\ ${ }^{4}$ Electrical Engineering Department, Faculty of Engineering, Universitas Lampung \\ ${ }^{5}$ Taman Kupu-Kupu Gita Persada, Lampung \\ *Corresponding Author. Email: meizano@eng.unila.ac.id
}

\begin{abstract}
Traveling is part of the activities for doing tourism. We have experience in tourism destinations. Due to COVID-19, people have limitations on the mobilization to travel. In 2020, a report was telling that tourism is the most affected business sector. Since the pandemic, we need to change our interactions. Most of our activities are moved digitally. On the other hand, we still have needed to fulfil. It shows the urgency of technology development to embrace the people's experience (user experience). The needs of traveling to tourism destinations, supported by technology. Developing a virtual tour in butterfly park has an urgency to stress spreading the knowledge of butterfly conservation, and it relies on the experience of doing the tourism. Tourist experience has to enable the feeling of being involved in the situation. Understanding the components is essential to the occasion. There are critical components for developing the user experience in Butterfly Park. We need a database on existing butterflies, vegetation (plants and flowers), and the butterfly park map. The virtual tourist can experience sight (seen using eyes) and sound (hear by ear), but they cannot feel by touch. That becomes the challenge for the development of these technologies. Taman Kupu-Kupu Gita Persada Virtual Reality Tour able to replicate some experience to users in visiting virtual tourist spots, viewing information on virtual tourist spots, and chose a location for virtual tourist spots. It is quite effective as a medium to experience tour and learn about conservation based on usability survey which resulted in $95 \%$ visitors are satisfied. Tourist experience is enabled the feeling of being involved in the situation by using Taman Kupu-Kupu Gita Persada Virtual Reality Tour. The experience will raise awareness for Sumatran butterfly conservation.
\end{abstract}

Keywords: Virtual Tour, Butterfly Conservation, Sumatran, User Experience

\section{INTRODUCTION}

Since 1998, Taman Kupu-Kupu Gita Persada in Lampung has provided education on butterfly metamorphosis, butterflies and plants diversity, and conservation. Through edu-ecotourism, Taman KupuKupu Gita Persada has been involved thousands of students from kindergarten to higher education's learning until now.
Due to the COVID-19 pandemic, edu-ecotourism activities cannot be done because schools activity limited to online learning [1]. In April 2020, 96\% of world tourism destinations had introduced travel restrictions [2]. In Indonesia, even on a public holiday, people were not allowed to travel [3]. This challenges in the tourism industry, as reported, caused a significant impact during the COVID-19 pandemic [4]. 
The primary drivers for traveling are the need to escape from daily routine, workplace, and social needs such as meeting other people and experiencing something unique or unusual [5]. Traveling is part of the activities for doing leisure and responding to the pandemic, raising the urgency for technology development to recreate the people's experience (user experience) in tourism activities. A virtual tour is one of the possibilities provided by technology. Having a virtual tour can never replace traditional travel, although it still has an exciting advantage [6].

\section{VIRTUAL REALITY TOUR}

Virtual reality enable user to have immersive interaction with virtual world. Virtual reality can also be a viable instrument to increase destination sustainability, provide another option for a wider audience, and help the environmental and economic aspects by developing alternate forms of income [10]. There are four critical elements in Virtual Reality: virtual world, immersion, interactivity, and sensory feedback. Virtual Reality replaces spatial reality to change the (illusion) environment for the user. One of the techniques is using a 360-panorama image to change the user visual perception.

A virtual tour maintains visitor interest, especially during travel restrictions in the COVID-19 pandemic [7]. Virtual tour through virtual reality act as a replacement for visiting recreation places physically. As for the visitor, virtual reality tourism can enhance the well-being of visitors [8]. In the future, audience who enjoyed and informed by the virtual tour can lead to actual visit to the tourism attraction [9].

There is a particular urgency to develop a virtual tour in butterfly park to spread the knowledge of butterfly conservation, and it relies on the tourist experiences. Tourist experience has to enable the feeling of being involved in the situation. The experience will raise awareness for Sumatran butterfly conservation.

\section{METHODOLOGY}

These three stages in the research methodology: motivation, design solution, and feedback (Figure 1). Motivation would be stressing on expectation of visitors. Design solution for development of features of virtual tour. Feedback is required to measure usability.

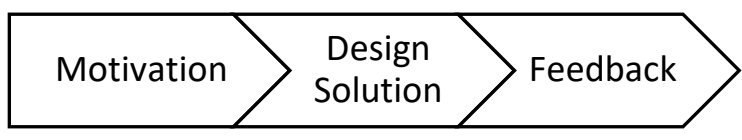

Figure 1 Research methodology

In drawing the motivation on virtual tour, the preliminary questionnaires were distributed to 100 respondents through an online form. Since the mobility of people is limited (people are forbidden to do traveling), we were asking the respondent who had already visited Taman Kupu-Kupu Gita Persada. We highlight the information on the reason for visiting Taman Kupu-Kupu Gita Persada and their activities in the park.

To address the visitor requirement as basis of design solution, at least three functional features must be available: (1) visiting virtual tourist spots, (2) viewing information on virtual tourist spot, and (3) selecting a virtual tourist spot with the location menu or map.

In measuring feedback, System Usability Scale used to measure usability of virtual reality tour visitors. The scoring system is simplified into four Likert scales, an even number so the visitor will be more likely to sway opinion to the left or right of the scale. The scale ranges from Very Dissatisfied, Dissatisfied, Satisfied to Very Satisfied. The intention is to acquire quick feedback on the visitor's experience.

\section{RESULTS AND DISCUSSION}

\section{1. Motivation}

On the point of ecotourism, the transfer of knowledge is also the primary purpose of ecotourism. As the main attraction in Taman Kupu-Kupu Gita Persada is butterflies, it is essential to provide extensive information/interaction on butterflies. It refers to designed activities on a virtual tour that should provide interactions on butterfly behavior (eating nectar, flying, resting, and matting) and metamorphosis of butterfly (caterpillar, cocoon, butterfly).

As the source of experiences, tourism gives tourists the power to be involved in the co-creation of tourism experiences [10]. Before traveling, tourists will search for activities that can be done in the tourism destination. They would find information on the internet or by recommendation from other. 
Table 1. Activities in Gita Persada Butterfly Park

\begin{tabular}{|l|l|c|}
\hline No & Activities & Percentage \\
\hline 1 & Walking around the park & 83 \\
\hline 2 & Seeing butterflies all around & 72 \\
\hline 3 & $\begin{array}{l}\text { Seeing butterflies in the breeding } \\
\text { dome }\end{array}$ & 64 \\
\hline 4 & $\begin{array}{l}\text { Taking a photo of butterfly's } \\
\text { statue }\end{array}$ & 43 \\
\hline 5 & $\begin{array}{l}\text { Sitting on a bench in an open } \\
\text { area }\end{array}$ & 42 \\
\hline 6 & Visiting the museum & 35 \\
\hline 7 & Visiting one of the treehouses & 34 \\
\hline 8 & $\begin{array}{l}\text { Seeing the cocoons in the } \\
\text { breeding dome }\end{array}$ & 32 \\
\hline 9 & $\begin{array}{l}\text { Seeing caterpillars in the } \\
\text { breeding dome }\end{array}$ & 30 \\
\hline 10 & Playing in the playground & 28 \\
\hline 11 & Using the prayer room & 14 \\
\hline 12 & $\begin{array}{l}\text { Getting explanations from the } \\
\text { officer }\end{array}$ & 11 \\
\hline 13 & Doing a forest bath & 9 \\
\hline 14 & Using the meeting hall \\
\hline 15 & Using a hammock & \\
\hline
\end{tabular}

Based on Table 1., the information of five primary activities chosen (done) by visitors gives input for the designed virtual tour. Virtually, the visitors have to be experiencing walking around the garden area, seeing butterflies all around, seeing butterflies in the breeding dome, taking photos on butterfly's statue, and sitting on a bench in an open space. Referring to those activities, we can point out related information into place, activities/movement, and points of interest. The critical information for the tourism domain is to know how tourists choose where to go and what to do [11]

For the effective integration of e-commerce and ecological tourism development activities, the development should be (1) providing information to tourists, (2) assisting tourists on navigation and security, and (3) enabling mobile payment functions [12]. It could improve the marketing management to reach the targeted customer, and the technology development should support it. Furthermore, it could help the ecotourism industry.

\section{2. Design Solution}

All the features required to provide virtual reality tour experiences are Can select a virtual tourist spot with the location menu or map, View information on virtual tourist spot, and Visit virtual tourist spots, as shown in Table 2. The virtual tour is based on virtual reality technology; several features must be provided, such as stereoscopic display, 3D virtual world, traversal either through locomotion or teleportation.
Table 2. Virtual reality tour features

\begin{tabular}{l|l}
\hline \multicolumn{1}{c|}{ Virtual Reality Tour Features } & Display \\
\hline $\begin{array}{l}\text { Can select a virtual tourist spot with the } \\
\text { location menu or map. }\end{array}$ & Figure 2 \\
\hline $\begin{array}{l}\text { View information on virtual tourist } \\
\text { spots }\end{array}$ & Figure 3 \\
\hline Visit virtual tourist spots & $\begin{array}{l}\text { Figure 4 } \\
\text { Figure 5 } \\
\text { Figure 6 }\end{array}$ \\
\hline
\end{tabular}

Others essential component of virtual tour experience is the database of existing butterflies, the database of vegetation (plants and flowers), and map of the butterfly park (Taman Kupu-Kupu Gita Persada), which will be vital for the asset of virtual reality tour.

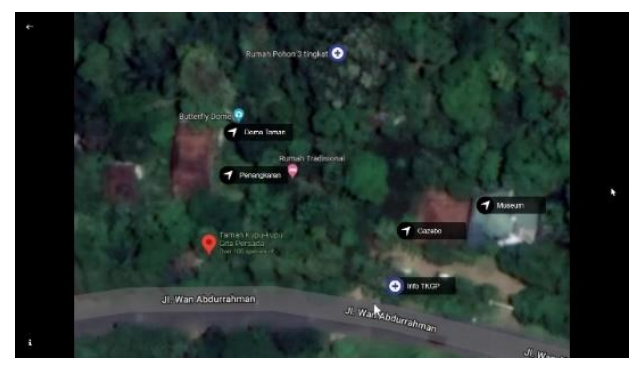

Figure 2 Virtual tourist spot

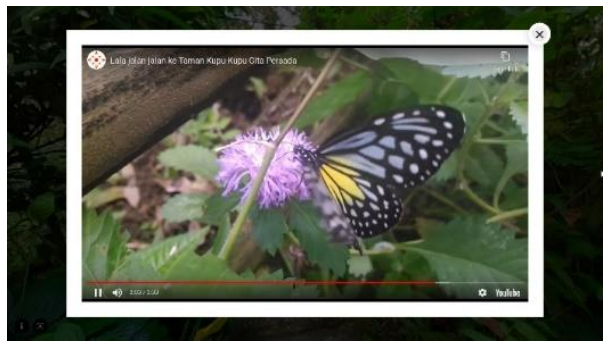

Figure 3 Information's display

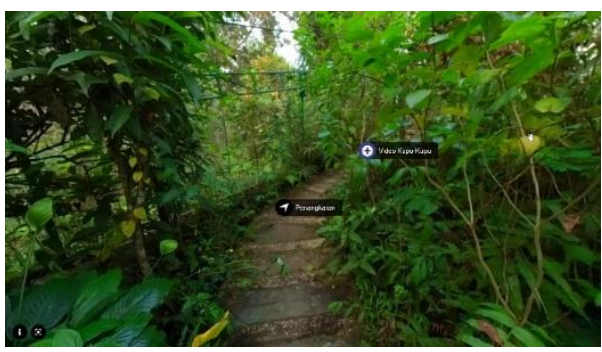

Figure 4 Virtual tourist spot 1

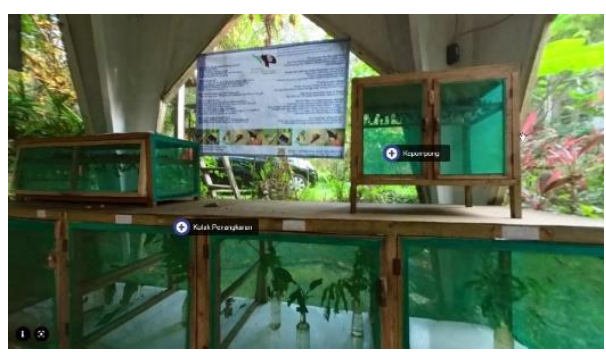

Figure 5 Virtual tourist spot 2 


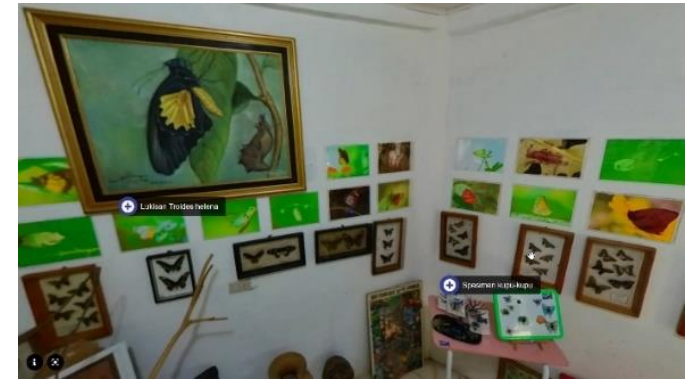

Figure 6 Virtual tourist spot 3

\section{3. Feedback}

\section{Results}

Virtual Reality Tour for Butterfly Park provides the experience of visiting Butterfly Park by keeping a few crucial aspects such as butterfly viewing, park traversal, and information gathering.

Some compromises need to be made because of the limitation of virtual reality tours, such as sensory feedback through audio-visual only and teleportation instead of locomotion.

Table 3. Taman Kupu-Kupu Gita Persada Virtual Reality Tour Testing

\begin{tabular}{|c|l|l|c|}
\hline No & \multicolumn{1}{|c|}{ Scenario } & \multicolumn{1}{|c|}{ Expected Result } & Fit? \\
\hline 1 & $\begin{array}{l}\text { Visit virtual tourist } \\
\text { spots. }\end{array}$ & $\begin{array}{l}\text { User visit tourist spot } \\
\text { in Virtual Reality }\end{array}$ & Yes \\
\hline 2 & $\begin{array}{l}\text { View information on } \\
\text { virtual tourist spots. }\end{array}$ & $\begin{array}{l}\text { The information } \\
\text { displayed on tourist } \\
\text { spot }\end{array}$ & Yes \\
\hline 3 & $\begin{array}{l}\text { Can select a virtual } \\
\text { tourist spot with the } \\
\text { location menu or map. }\end{array}$ & $\begin{array}{l}\text { User teleport to a } \\
\text { chosen location. }\end{array}$ & Yes \\
\hline
\end{tabular}

Virtual Reality Tour is tested using scenarios based on features (Table 3). All the features proposed in the design are implemented accordingly.

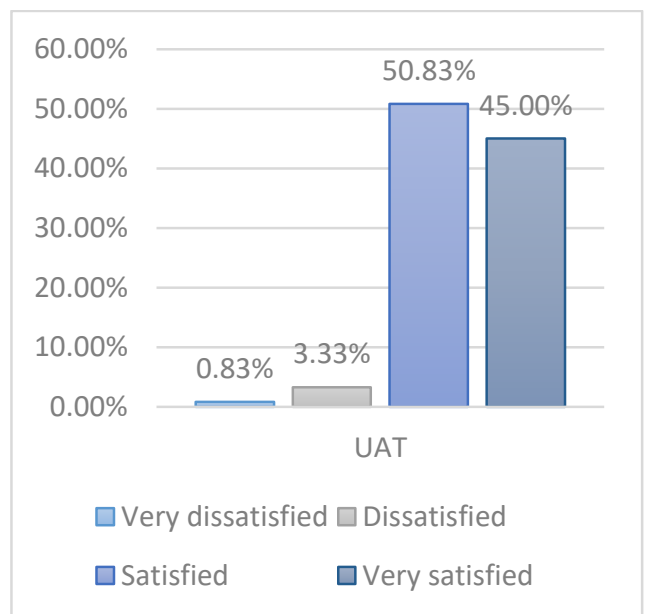

Figure 7 User Acceptance Test of Virtual Reality Tour
Feedback from the usage of virtual reality tour show promise of good usability. More than $95 \%$ of visitors were satisfied with the Taman Kupu-Kupu Gita Persada virtual reality tour. Most visitors express understanding of the butterfly conservation and show support for the cause.

\section{CONCLUSION}

There is a particular urgency to develop a virtual tour in butterfly park to spread the knowledge of butterfly conservation, and it relies on the tourist experiences. Taman Kupu-Kupu Gita Persada Virtual Reality Tour can replicate some experience to users in visiting virtual tourist spots, viewing information on virtual tourist spots, and chose a location for virtual tourist spots. The Virtual Reality Tour is quite effective as a medium to experience tour and learn about conservation based on usability survey which resulted in 95\% visitors are satisfied. Tourist experience is enabled the feeling of being involved in the situation by using Taman Kupu-Kupu Gita Persada Virtual Reality Tour. The experience will raise awareness for Sumatran butterfly conservation.

\section{ACKNOWLEDGMENTS}

We would like to express our gratitude to Taman Kupu-Kupu Gita Persada for their support in this research.

\section{REFERENCES}

[1] G. P. Djausal, A. Larasati, and L. Muflihah, "Strategi Pariwisata Ekologis Dalam Tantangan Masa Pandemi Covid-19," Jurnal Perspektif Bisnis, vol. 2, no. 1, pp. 57-61, 2020.

[2] BBC News Indonesia, "Covid-19 dan aktivitas pariwisata Indonesia: 'Wisata balas dendam', turis diprediksi melonjak setelah pembatasan sosial, 'Saya tidak mau mati konyol karena jalan-jalan' BBC News Indonesia," May 19, 2020. https://www.bbc.com/indonesia/indonesia52721983 (accessed Nov. 25, 2021).

[3] Sindonews.com, "Selama Larangan Mudik, Warga Luar Bogor Dilarang Liburan ke Puncak," May 11, 2021.

https://metro.sindonews.com/read/425052/170/sela ma-larangan-mudik-warga-luar-bogor-dilarangliburan-ke-puncak-1620723957 (accessed Nov. 25, 2021).

[4] UNWTO, "Tourism and COVID-19 unprecedented economic impacts | UNWTO." https://www.unwto.org/tourism-and-covid-19unprecedented-economic-impacts (accessed Nov. 25, 2021). 
[5] E. Šimková and J. Holzner, "Motivation of Tourism Participants," Procedia - Social and Behavioral Sciences, vol. 159, pp. 660-664, Dec. 2014, doi: 10.1016/J.SBSPRO.2014.12.455.

[6] Rani Rastati, "Virtual Tour: Tourism in the Time of Corona," 6th International Conference on Social and Political Sciences (ICOSAPS 2020), 2020.

[7] J. Cave and D. Dredge, "Regenerative tourism needs diverse economic practices," https://doi.org/10.1080/14616688.2020.1768434, vol. 22, no. 3, pp. 503-513, May 2020, doi: $10.1080 / 14616688.2020 .1768434$.

[8] Y. Li, H. Song, and R. Guo, "A Study on the Causal Process of Virtual Reality Tourism and Its Attributes in Terms of Their Effects on Subjective Well-Being during COVID-19," International Journal of Environmental Research and Public Health, vol. 18, no. 3, p. 1019, Jan. 2021, doi: 10.3390/ijerph18031019.

[9] O. El-Said and H. Aziz, "Virtual Tours a Means to an End: An Analysis of Virtual Tours' Role in Tourism Recovery Post COVID-19," Journal of Travel Research, p. 004728752199756, Mar. 2021, doi: $10.1177 / 0047287521997567$.

[10] E. Binkhorst and T. Den Dekker, "Agenda for cocreation tourism experience research," Journal of Hospitality and Leisure Marketing, vol. 18, no. 23, pp. 311-327, 2009, doi: $10.1080 / 19368620802594193$.

[11] A. Charoenpruksachat and P. Longani, "Effectiveness of a Tourism Game for Identifying Travelers' Behaviors," 2020 Joint International Conference on Digital Arts, Media and Technology with ECTI Northern Section Conference on Electrical, Electronics, Computer and Telecommunications Engineering, ECTI DAMT and NCON 2020, pp. 186-189, Mar. 2020, doi: 10.1109/ECTIDAMTNCON48261.2020.9090696.

[12] Z. Lianfeng, "Research on the application of mobile e-commerce in ecotourism," Bulletin of Sumy National Agrarian University, no. 2(80), pp. 27-31, Feb. 2019, doi: 10.32845/bsnau.2019.2.5. 